\title{
sobre: La garra suave. Representaciones de Miguel Hernández como escritor popular, de Sabrina Riva. salamanca:
}

\author{
Ediciones Universidad de Salamanca, 2017. \\ MARÍA BELÉN BERNARDI Universidad Nacional de Rosario - CONICET, Argentina / \\ mariabelenbernardi@gmail.com
}

El presente libro de Sabrina Riva es producto de una investigación que tiene como punto de partida su tesis doctoral, desarrollada en la Universidad de Alicante y galardonada con el Premio USAL-TALENTO convocado por la Universidad de Salamanca.

La senda de los estudios hernandianos, recorrida prolífica y sólidamente por la autora, se centra en esta oportunidad en el abordaje de dos ejes fundamentales, cuyo horizonte mantiene constante el vínculo indisoluble entre consideraciones a un tiempo biográficas y poéticas. El primer eje se basa en las operaciones de lectura y reescritura que realiza Hernández de distintas tradiciones, principalmente la oral, popular, pero también aquellas provenientes del Siglo de Oro, las vanguardias y la incipiente poesía social, en pos de delinear un proyecto y una propuesta poética propios, considerando además las instancias de producción, circulación y recepción en que dicho programa se inscribe. El segundo eje se encuentra constituido por las diversas imágenes que, a partir de una amplia variedad de géneros, se construyen en torno al poeta y que pueden resumirse, básicamente, en «tres tristes tópicos» (Sánchez Vidal): la figura del «poeta pastor», del «poeta del pueblo» y del «poeta del sacrificio».

El desarrollo de estos tópicos supone a la vez la conformación, el asentamiento en el imaginario popular y la elevación a un rango legendario de otras imágenes complementarias del poeta que, tal como advierte la autora en las primeras páginas, se apuntalan mutuamente en un «dilatado y complejo puzzle» cuyo trazado y rearmado constituye uno de los principales objetivos del libro.

De esta manera, aparecen analizadas las representaciones de un «poeta soldado», «comprometido», «militante», «autodidacta», «pedagogo», «juglar», «niño», «ingenuo», «prisionero», «heroico», «enamorado», «raro», «endemoniado», «incomprendido», «romántico», entre otras que son objeto de distintos tratamientos en función de los sujetos involucrados, los propósitos perseguidos y las coordenadas sociohistóricas de emergencia de dichas imágenes.

Con una mirada lúcida, Riva construye un mapa de las operatorias y las estrategias que subyacen a la proclama de ciertos emblemas y advierte acerca de los peligros que conlleva la consolidación

\footnotetext{
Para citar este artículo: Bernardi, M.B. (2019). Sobre: La garra suave. Representaciones de Miguel Hernández como escritor popular, de Sabrina Riva. El taco en la brea, 10 (junio-noviembre), 209-211. Santa Fe, Argentina: UNL. DOI: 10.14409/tb.vii1o.8699
} 
de estereotipos que en ocasiones acaban por instaurar una lectura restringida e incluso sesgada del poeta oriolano. Por citar solo un ejemplo representativo, la forja de una figura de autor como "poeta católico", presente en una biografía de 1955, es "producto, en el mejor de los casos, de un intento por limpiar la imagen de poeta comunista —y por lo mismo antiespañol—, ateo y erótico de Hernández, ante la mirada atenta del franquismo; un ensayo en pos de pasar airoso la censura» (58).

En este punto, cabe destacar el desafío que ha asumido la investigadora al tomar como objeto de análisis una ingente cantidad (y variedad) de materiales que tienen el valor de reponer fuentes provenientes no solo de la literatura sino también de otros campos artísticos, lo cual dota a este libro de una marca de originalidad que lo distingue de la profusa producción crítica existente en torno a la obra de Hernández.

Con un riguroso planteamiento metodológico y con la inclusión de registros visuales que denotan el monumental trabajo de archivo que sustenta su investigación, la autora analiza textos autopoéticos (Casas), biografías de diversa índole (literarias, heroicas, televisivas, en viñetas, prosobiografías, hagiografías, semblanzas presentes en autobiografías de escritores contemporáneos), libros infantiles ilustrados, novelas gráficas, documentales, miniseries, videocreaciones de tipo paródico y canciones de variadas épocas y géneros, la mayoría de los cuales gravita alrededor del centenario del nacimiento del poeta.

Del conjunto de dichos materiales, reviste especial interés el capítulo dedicado al vínculo entre Hernández y la canción de autor. En primer lugar debido a que permite vislumbrar en toda su potencia y vigencia la problemática que atraviesa el estudio en su totalidad: el complejo circuito conformado por los trasvases, las negociaciones y las reapropiaciones mutuas que permean las tradiciones cultas, populares y masivas, desde la perpetuación de una imagen de escritor comprometido y popular por parte de la canción de autor española de los años sesenta y setenta, hasta el pasaje a lo masivo que se produce a partir de canciones provenientes del pop y del rock que, si bien abandonan esta figura del compromiso y su consecuente componente crítico, contribuyen de todas maneras a ampliar los ámbitos de circulación de esta poesía. En segundo lugar, porque la mirada de la investigadora argentina recupera el fenómeno de la canción de autor que versiona poemas de Hernández considerando no solo España sino también Latinoamérica, en un gesto análogo al que le permite incluir en su marco teórico referentes críticos procedentes tanto del continente europeo como del latinoamericano, lo cual enriquece los modos de acercamiento a las problemáticas abordadas.

De este modo, se delimita el contexto histórico común de procesos revolucionarios y antidictatoriales que suceden simultáneamente en ambas orillas para enmarcar esta «nueva canción» que se levanta contra aquella comercial y de consumo y que tiene como representantes, entre otros, a Rosa León, Carlos Cano, Silvio Rodríguez, Pablo Milanés y Alfredo Zitarrosa.

Un apartado individual merece el caso Serrat, dada la enorme labor de difusión que llevó a cabo de la poesía popular tradicional española, no solo a partir de Hernández, sino también de Machado y Lorca (la «trilogía de poetas víctimas del franquismo»). En esa labor que en gran medida comparte con Hernández reside quizás la recuperación que realiza el cantautor de la figura de «poeta juglar» o "pedagogo», recordando que el poeta oriolano popularizaba lo culto de sus poemas de corte gongorino mediante el uso de carteles que ayudaban al público en la interpretación. En un segundo nivel de análisis, la autora se detiene también en las imágenes que el propio Serrat difunde de sí mismo en los discos a partir de la figura de Hernández, del diseño de los discos y de la selección de los versos a «traducir». 
En suma, la amplitud de los temas abordados en el libro a partir de múltiples aristas, y mediante un desarrollo ordenado y coherente, hacen de él un aporte valioso y necesario para un vasto público interesado en la obra del poeta oriolano.

«La garra suave», proveniente de la «Canción última» de Hernández, pone en acto el conjunto de su obra y reactualiza un lenguaje poético que la autora cultiva en múltiples rincones del libro, especialmente hacia el final, donde al igual que el poeta estudiado, reivindica la potencia transformadora de la palabra, creadora de mundos.

Refiriéndose al centenario del nacimiento de Hernández en 2010, la autora concluye: «éste fue un momento propicio para revisar los alcances de su figura, en el marco de una intensa crisis económica que se prolonga hasta nuestros días, signada por los recortes y el desempleo, pero también por muestras renovadas de participación ciudadana. Integrado de modo decidido en la nómina de los mitos nacionales, su ejemplo es evocado, en estas nuevas circunstancias, pues sus cualidades morales siguen teniendo la potencia de un "arma política". "Poeta de la resistencia", sin embargo, su espacio no es el de la política ni el de la moral. Su figura, popular e inexpugnable, se sitúa, definitivamente, en el siempre necesario terreno de los insumisos» (244). 